\title{
ROLE OF ENGLISH AFFIXOIDS IN MODERN UKRAINIAN, RUSSIAN AND FRENCH
}

\author{
O. Samoilenko \\ Head of the Department of Language and Humanitarian disciplines № 1, \\ Donetsk national medical university \\ helen11071985@gmail.com \\ orcid.org/0000-0001-5040-874X
}

Introduction. The processes of borrowing influences greatly the word-building systems of modern languages. The vocabulary of languages is enriched due to direct borrowing of lexemes, calques and semi-calques, borrowing of word-patterns and of foreign morphemes. From our point of view, borrowing of affixoids allows not only to add new morphemes, but also such morphemes can develop new semantic meanings.

So, in modern languages it is possible to observe the tendency to economizing language efforts: instead of phrases and word-combinations we use compound words which are built according to the models which are characterized by a high degree of productivity in languages. New words are created not on only the basis of the unit of the syntactical level in the language, but by adding some repeating component which has semantic meaning. Very often in such cases elements in pre-position and elements in post-position perform functions of affixes (for example, classifying and generalizing). These elements may be called affixoids (similar to affixes).

The aim of the article is to reveal the peculiarities of the influence of borrowings from English on the word-building subsystem of the target languages and namely to define the role of affixoids in productive ways of modern word-building. The aim preconditions the performing of the following tasks: 1) analysis of the nature of affixoids; 2) revealing peculiarities of borrowed affixoids functioning in target languages.

Methods of research. In the article the following methods are used: 1) for detecting the volume and meaning of the term affixoid the method of the review of the existing literature has been used; 2) for revealing the constituent parts of the lexical units the method of distributive has been used; 4) for describing the peculiarities of quasi-composites and existing word-patterns the methods of onomasiological and formal analysis have been used.

Results and discussion. The problem of affixoids has become quite popular in the modern linguistic literature. In general, up to present time, linguists have not yet agreed on the definition of the linguistic status of such components: they are called affixoids (Selivanova, 2000), relatively free/relatively bound morphemes (Kubryakova, 1977), affixed bases (Shanskiy, 1973), bound supporting components (Lopatin, 1973), international terminological elements, semi-affixes (Ryazanov, 2000), combining forms, subaffiixes. According to R. Safin, such morphological units are: 1) bound morphemes of special type; 2) used only in conjunction with other affix or root components; 3) have individual lexical meaning; 4) capable of acquiring the generalizable meaning which is similar to the categorizing meaning of affixes. We support the view that such elements have the status of an affixoid, since the composites they include cannot be deployed in a phrase. In addition, these components have a generic lexical meaning: something related to water (hydrophobia. hydrology, hydropark). Thus, such entities have the status of prefixes in the preposition and the status of affixoids in the postposition. R. Safin considers the above-mentioned units to be transitional type morphemes. They function both as roots and affixal morphemes (Safin, 1974).

In modern linguistics science while analyzing and making the review of the existing literature it is possible to differentiate four criteria for identifying affixoids: quantitative, formal, functional, semantic, criterion of the ability of the affixoid to be used in corresponding word- 


\section{Ukrainian sense. 2020. ISSN 2313-4437}

combination or sentence as an independent word (the criterion of the expandibility into a unit of the syntactical level). As for the quantitative criterion, scholars try to analyse productivity of morphemes as a key principle for differentiating affixoids into a specific group of morphemes. Some linguists (Stepanova, 1953; Bartkov, 1978) underline that the regularity of the reproduction is the main criterion for it: affixoids are more productive than root morphemes, but less productive than suffixes or prefixes, so they are on half-way from roots to affixes.

The supporters of the formal criterion write about the external form of words, containing affixoids and offer their characteristic features: the presence of a connecting, the fixed place of some elements in the word (Shanskiy, 1973).

The functional criterion of affixoids is based on their ability to perform a certain function (to express semantic categories: profession, field, sign, status etc.). The ability to carry out this function can be proved with the help of onomasiological analysis by using the notions of onomasilogical basis and onomasiological sign. For example, the English suffix -er is used to denote the category "doer of the action", the English affixoids -man and -person can also be used in such a function. In Ukrainian the suffixoid -знавець is used in the meaning "specialist in some field", in Russian word-building elements -вед, -вод. This criterion is very controversial because describes such units of intermediate status as morphemes which are very close to real affixes.

The main semantic characteristic feature of affixoids is considered to be their loss of specific lexical meaning and the acquisition of new generalized meaning as a part of a quasicomposite word.

The essence of the semantic criterion of deployability-non-deployability can be explained by the ability / inability of the word to deploy into a semantically motivating word combination, the loss of such a character feature signals that one of the components of the word functionally approaches to the affix (Bartkov, 1978; D’yachkova, 2011).

If one analyses the appearance of the affixoid. -gate, it is necessary to take into consideration, that it is formed due to the so-called "intercalated" or "telescopic" formation of new words, when one word is "inserted" into another, as a result of which an unusual, occasional formation appears.

Originally the word Watergate has become the source for the affixoid -gate. Oxford Guide to British and American Culture Says that Watergate is "the US political scandal that forced President Richard Nixon to leave office in 1974. It involved Republican Party members who in 1972 tried to steal information from the offices of the Democratic party in the Watergate building in Washington, DC. Nixon said he did not know about this, but The Washington Post and tapes of his telephone conversation proved he did. He resigned as Congress was about to begin impeachment, and several important government officials were sent to prison for illegally trying to keep the affair secret. The Watergate incident made the role of the President weaker for several years and many people were shocked that people in power had behaved so badly. The word-ending-gate has since been used to create names for other scandals" (Oxford Guide to British and American Culture, 2005)

The word Watergate is a proper name, and the meaning "political scandal" has developed in it. Later, as such words-hybrids are accumulated in the language, the final syllable -gate gradually becomes an evaluative morpheme, independently participating in the formation of new words. Ukrainian and Russian have also borrowed this affixoid and most of Ukrainian and Russian learners do not know about the primary meaning of this root: Моникагейт: как президент Клинтон чуть не угодил в тюрьму (Мир24. 12.02.2019)

In modern Ukrainian and Russian we can reveal the development of new meaning which is absolutely different from the primary meaning "a door in a fence or outside; the place where you leave an airport building to get on the plane.". Some people are even sure that -gate is the synonym of the word scandal. The high degree of assimilation of the English affixoid can be proved by a number of examples from Ukrainian and Russian mediatexts which describe the reality of these countries: Свинарчукгейm, Украинагейт: СвинарчукГейт: Компанія "Укроборонпрому" мала договір про спільну діяльність з компаніями друзів Гладковського- 


\section{Ukrainian sense. 2020. ISSN 2313-4437}

молодшого (https://statewatch.org.ua/publications/svynarchukheyt-kompaniia-ukroboronpromumala-dohovir-pro-spil-nu-diial-nist-z-kompaniiamy-druziv-hladkovs-koho-molodshoho).

The adoption of -gate to suggest the existence of a scandal was promoted by William Safire, the conservative New York Times columnist and former Nixon administration speechwriter. As early as September 1974 he wrote of "Vietgate", a proposed pardon of the Watergate criminals and Vietnam War draft dodgers. Subsequently, he coined numerous -gate terms, including Billygate, Briefingate, Contragate, Deavergate, Debategate, Doublebillingsgate, Frankiegate, Franklingate, Genschergate, Housegate, Iraqgate, Koreagate, Lancegate, Maggiegate, Nannygate, Raidergate, Scalpgate, Travelgate, Troopergate and Whitewatergate. There is a theory that the above-mentioned group of words was created to minimize the guilt of R. Nixon, to make the audience laugh and not take the situation too serious.

Several similar compounds with the -gate component were created by international journalist M. Sturua: ЦРУгейm, ФРГгейт, угольгейт, космогейт, Большойгейт (Bolshoi Theater). New lexical units with such a: Кучмагейm (Gongadze case), Рахатгейm (failed coup in Kazakhstan) etc.

Since that time the list of gates has become much longer. According to the Internet sauces it is possible to count 243 lexical units with the component -gate. These lexical units can be classified according to the sphere of their origin and usage: art and entertainment (Comicsgate, Donutgate, Gamergate, Tomato-gate), journalism and academics (Climategate, Facebookgate, Ubergate), politics (Angolagate, Bananagate, Biscuitgate, Chinagate), sports (Bloodgate, Coughgate, Homeworkgate, Tatoogate), technology (Hissgate, Santagate, Webbcamgate).

From the point of view of onomasiology the word-building element -gate represents the onomasiological basis event and the following onomasiological signs:

- reason: Resolutiongate, Toiletgate, Elbowgate, Coalgate, Cashgate;

- location: Indygate (scandal at Indianapolis Motor Speedway), Shawinigate, Panamagate;

- participants: Tigergate (connected with marital infidelities of golfplayer Tiger Woods), Dianagate, Monicagate, Camillagate.

Cases of independent use of the word-element -gate with the meaning of "political scandal" have been also revealed, that confirms its status between the root and the affix: “...всевозможные “гейты””, разные по степени скандальности и масштабам последствий, случаются чуть ли не каждый месяи”" (Известия. 18.10.2007.).

It is very interesting to note that the morpheme -gate functions independently in computer terminology, expressing the meaning "gate for sending mail to other zones of the network", and it is able to make up new compounds in Russian: факсгейты, пейджергейты, and as a root morpheme it can be found in the abstract noun zейтсистемa.

But there is an alternative point of view. C. Hamans points out that in case -gate should be described as an affixoid, then one might have expected at least a minimal, bleached aspect of the original meaning to have remained. He calls such lexical units the result of libfixing.

Borrowing word-forming models is another character feature of language that causes the appearance of quasi-composites. In French, for example. it is possible to observe the interesting phenomenon of borrowing not structural parts, but word-building samples. For example, in English the structural model of creation of quasi-compound noun "noun + suffixoid -man" is very productive: spaceman, yachtsman etc. In French, there are also many Englishisms with the following constituent: sportsman, bussinessman and so on. Frenchmen even use the lexical unit tennisman, by copying the English word-formation model and using the law of analogy. By the way, there is not such a word in English. Its equivalent is the word-combination tennis player. Thus, in French there is a word that consists of English-language elements, but does not exist in the source language. In general, there are many examples of borrowing a word-forming model in French. M. Hofler even suggests for them the term "false Englishisms", which means "words created in French with the help of English elements", for example, fly-tox, silent-bloc, baby-parc, baby-foot, baby-beef, moto-ball, ball-trap, auto-stop, crossman, rugby-man. They were formed on the basis of English elements by using word-forming models of the sauce language in French, but 


\section{Ukrainian sense. 2020. ISSN 2313-4437}

Francophones perceive them as Englishisms. These words were created by analogy with existing borrowings and their models. Thus, on one hand, they are both French but on the other hand, they are formed by English elements. And since these lexical units do not exist in English, we consider them to be "false Englishisms" and, together with other borrowings, refer to quasi-composites. The presence of "false Englishisms" in the French language proves once again that very often not separate words are borrowed, but also word-building material.

As for the Slavic languages, at present we can talk about the emergence in the Russian language under the influence of English new word-forming model, when new complex lexical units are formed on the basis of two independent nouns borrowed from English language: бизнес-леди, рок-клуб, гей-кафе. But also word-formation models that are not characteristic of the recipient language. This suggests that borrowing can affect not only the lexical subsystem of a particular language, but also enrich its word-forming system, adding new forms and models.

Based on all the above, we can conclude that in modern languages such elements receive the status of affixoids, which take an active part in word-forming processes based on the recipient language (using both borrowed models and native lexical material). On the other hand, affixoidation of borrowed word elements leads to the emergence of so-called false Englishisms. For example, the word шопmyp, which is well understood by native speakers of Ukrainian and Russian, does not actually exist in English, and therefore cannot be called English in the full sense of the word. In our opinion, in such cases it is necessary to talk about a separate borrowing of two elements and their combination into a complex word in the recipient language. The update of this word-forming model can be found, for example, in the composite armomyp. The absence of the word umonmyp in the probable source language is explained by the fact that in Western countries there is no practice of travelling abroad to buy clothes or get a car, so the word was formed exclusively on domestic soil. In general, a number of tokens with a borrowed affixoid $-\boldsymbol{m y p}$ were formed in Ukrainian and Russian: иуб-тур, секс-тур and even the occasional word лох-тур. All these complex words act as quasi-composites formed on the model productive in English.

Conclusion. Processes of borrowing influence the target languages in many different ways. The most common of them is direct borrowing, assimilation of concrete lexical units. But recently the facts of influence of the source language have become more and more common, so processes of borrowing have an impact not only on the lexical subsystem of the target language, but also on the word-building level by assimilating productive affixes and affixoids, as well as common wordbuilding patterns and models. The field of affixoids still requires new linguistic research, especially in connection with the processes of borrowing and the tendency of the modern languages to simplification. It is very important to observe new ways of enriching vocabulary where assimilation of foreign affixoids is becoming more and more productive. The independent functioning of affixoids in target languages is also worth describing and analyzing.

\section{REFERENCES}

Bartkov, B. I. (1978). O statuse slovoobrazovatel'nykh morfem tipa -smith, -proof, -tight v angliyskom yazyke [About the status of word-building morphemes -smith, -proof, -tight in English]. Slovoobrazovanie i ego mesto v kurse obucheniya inostrannomu yazyku - Word-building and its place in studying a foreign language, 6, 42-51 [in Russian].

D'yachkova, E. S. (2011). Polusuffiksy i obrazovaniya s nimi v sovremennom angliyskom yazyke [Semi-suffixes and new words with them in the modern English language]. Candidate's thesis. Barnaul [in Russian].

Zacnyj, Ju. A. (1999). Rozvytok slovnykovogho skladu anghlijsjkoji movy v 80 ti 90 -ti roky XX stolittja [The development of English vocabulary in the 1980s and 1990s of the XX c.]. Candidate's thesis. Kyiv [in Ukrainian].

Klymenko, N. F. (2008). Dyferencijni ta integhracijni procesy v leksyci ta slovotvori suchasnoji ukrajinsjkoji movy [Differentiating and integrating processes in Ukrainian lexics and word-building]. Movoznavstvo - Linguistics, 2-3, 136-147 [in Ukrainian]. 


\section{Ukrainian sense. 2020. ISSN 2313-4437}

Kubryakova, E. S. (1977). Semantika sintaksisa i nekotorye problemy teoriii slovoobrazovaniya [Semantics of syntacsis and some problems of word-building theory]. Sbornik nauchnykh trudov Moskovskogo gosudarstvennogo instituta inostrannykh yazykov im. Morisa Toreza - Collection of Scientific Works of Moscow State Institute of Foreign Languages, 112, 123 133 [in Russian].

Levkovskaya, K. A. (1955). Retsenziya na knigu M. D. Stepanovoy [Review of the book by M. D. Stepanova]. Voprosy yazykoznaniya - Questions of Linguistics, 1, 146-150 [in Russian].

Lopatin, V. V. (1973). Rozhdenie slova. Neologizmy i okkazional'nye slova [Birth of a word. Neologisms and occasionalisms]. Moskva: Nauka [in Russian].

Motashko, V.P. (1984). K voprosu o nominativnykh yazykovykh edinitsakh neopredelennogo slovoobrazovatel'nogo statusa (na materiale novoobrazovaniy frantsuzskogo yazyka) [About the question of nominative unite of indefinite word-building status (on the material of French)]. Novye yavleniya i tendentsii vo frantsuzskom yazyke - New Phenomena and Tendencies in French, 1, 59-75 [in Russian].

Ryazanov, V. Yu. (2000). Osobennosti sinkhronnykh svyazey slovoslozheniya i affiksatsii v sovremennom angliyskom yazyke [Peculiarities of synchronic links of word-building and affixation in English]. Candidate's thesis. Moskva [in Russian].

Safin, R. A. (1974). Status morfem tipa grapho- i -logy [Status of morphemes such as grapho- and logy-]. Voprosy terminologii i lingvisticheskoy statistiki - Questions of Terminology and Linguistic Statistics, 48-54 [in Russian].

Selivanova, O. O. (2000). Linghvistychna encyklopedija [Linguistic encyclopaedia]. Poltava: Dovkillja-K [in Ukrainian].

Stepanova, M. D. (1953). Slovoobrazovanie sovremennogo nemetskogo yazyka [Wordbuilding of modern German]. Moskow: Izdatel'stvo literatury na inostrannykh yazykakh [in Russian].

Shanskiy, N. M. (1973). Leksikologiya sovremennogo russkogo yazyka [Lexicology of modern Russian]. Moskow: Prosveshchenie [in Russian].

\section{Анотація}

Постановка проблеми. Статтю присвячено дослідженню впливу запозичених афіксоїдів на словотвірні підсистеми мов-реципієнтів.

Метою статті є розкриття особливостей впливу запозичень з англійської мови на словотвірні підсистеми мов-реципієнтів, а саме визначення ролі афіксоїдів у продуктивних способах сучасного словотворення. Мета передбачає виконання наступних завдань: аналіз природи афіксоїдів, виявлення особливостей запозичених афіксоїдів, щэо функціонують у мовах-рецинієнтах.

Методи дослідження. У статті використано наступні методи: 1) для виявлення обсягу та значення терміну афіксоїд використано метод аналізу літературних джерел; 2) для виділення та аналізу складових частин лексичних одиниць використано метод дистрибутивного аналізу; 3) для опису особливостей квазікомпозитів та існуючих словотвірних зразків використано методи ономасіологічного та формального аналізу.

Основні результати дослідження. Під час аналізу етимології афіксоїда -gate, потрібно врахувати, щзо його утворено внаслідок так званого “інтеркальованого” або “телескопічного” утворення нових слів, коли одне слово “вставляється” в інше.

У сучасних украӥнській і російській мовах можна виявити розвиток нового значення, що абсолютно відрізняється від первинного значення. Подекуди наявна навіть упевненість, щзо -gate є синонімом слова “скандал”, без співвіднесення ичього афксоїда з його первинним значенням “ворота".

Запозичення словотвірних моделей - ще одна характерна риса мови, яка спричиняє появу квазікомпозитів. Наприклад, у франиузькій мові можна спостерігати цікавий феномен запозичення не структурних елементів, а зразків для побудови слів. Наявність у франиузькій мові “помилкових англічизмів" ще раз доводить, щэо часто запозичують не 


\section{Ukrainian sense. 2020. ISSN 2313-4437}

лише окремі слова, а й словотвірний матеріал.

Висновки і перспективи. Процеси запозичень впливають на мови різними способами. Найпотиреніший з них - пряме запозичення, засвоєння конкретних лексичних одиниць. Утім, останнім часом прочеси запозичення впливають не лише на лексичну підсистему мовиреципієнта, а ци на рівень словотворення через асиміляцію продуктивних афіксів та афіксоїдів, а також загальноприйняті словотвірні моделі й зразки. Вивчення афіксоїдів вимагає нових лінгвістичних досліджень, особливо у зв'язку з процесами запозичень та тенденцією сучасних мов до спрощення. Дуже важливо визначити та описати нові способи збагачення словникового складу, одним з яких є засвоєння іншомовних афіксоїдів.

Ключові слова: запозичення, квазікомпозит, афіксоїд, словотвірний зразок, ономасіологічна модель, ономасіологічний базис, ономасіологічна ознака.

\section{Abstract}

Background. The article is devoted to the influence of borrowed affixoids on the wordbuilding subsystems of the target languages.

Purpose. The aim of the article is to reveal the peculiarities of the influence of borrowings from English on the word-building subsystem of the target languages and namely to define the role of affixoids in productive ways of modern word-building. The aim preconditions the performing of the following tasks: analysis of the nature of affixoids; revealing peculiarities of borrowed affixoids functioning in target languages.

Methods. In the article the following methods are used: 1) for detecting the volume and meaning of the term affixoid the method of the review of the existing literature has been used; 2) for revealing the constituent parts of the lexical units the method of distributive has been used; 3) for describing the peculiarities of quasi-composites and existing word-patterns the methods of onomasiological and formal analysis have been used.

Results. If one analyses the appearance of the affixoid. -gate, it is necessary to take into consideration, that it is formed due to the so-called "intercalated" or "telescopic" formation of new words, when one word is "inserted" into another, as a result of which an unusual, occasional formation appears. In modern Ukrainian and Russian we can reveal the development of new meaning which is absolutely different from the primary meaning. Some people are even sure that gate is the synonym of the word scandal.

Borrowing word-forming models is another character feature of language that causes the appearance of quasi-composites. In French, for example, it is possible to observe the interesting phenomenon of borrowing not structural parts, but word-building samples. The presence of "false Englishisms" in the French language proves once again that very often not only separate words are borrowed, but also word-forming material.

Discussion. Processes of borrowing influence the target languages in many different ways. The most common of them is direct borrowing, assimilation of concrete lexical units. But recently the facts of influence of the source language have become more and more common, so processes of borrowing have an impact not only on the lexical subsystem of the target language, but also on the word-building level by assimilating productive affixes and affixoids, as well as common wordbuilding patterns and models. The field of affixoids still requires new linguistic research, especially in connection with the processes of borrowing and the tendency of the modern languages to simplification. It is very important to observe new ways of enriching vocabulary where assimilation of foreign affixoids is becoming more and more productive. The independent functioning of affixoids in target languages is also worth describing and analyzing.

Keywords: borrowing, quasi-composite, affixoid, word-pattern, onomasiological model, onomasiological basis, onomasiological sign. 